\title{
Acanthoparyphium shinanense n. sp. (Digenea: Echinostomatidae) from Experimental Chicks Infected with Metacercariae Encysted in Brackish Water Clams in the Republic of Korea
}

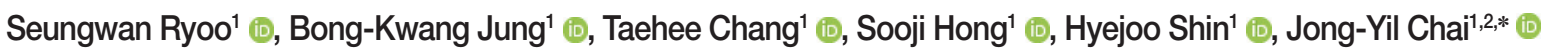 \\ ${ }^{1}$ Institute of Parasitic Diseases, Korea Association of Health Promotion, Seoul 07649, Korea; '2Department of Tropical Medicine and Parasitology, \\ Seoul National University College of Medicine, Seoul 03080, Korea
}

\begin{abstract}
Acanthoparyphium shinanense n. sp. (Digenea: Echinostomatidae) is described from chicks experimentally infected with the metacercariae encysted in 2 brackish water clam species, Ruditapes philippinarum and Coecella chinensis, in the Republic of Korea. The metacercariae were round to oval, armed with 23 collar spines, and $0.216(0.203-0.226)$ $\mathrm{mm}$ in diameter. From 5 chicks experimentally infected each with 200 metacercariae, 34 juvenile (5-day-old worms) and 104 adult flukes (7-day-old worms) were harvested from their small intestines, with the average worm recovery rate of 13.8\%. The adult flukes were $3.18(2.89-3.55) \mathrm{mm}$ long and $0.68(0.61-0.85) \mathrm{mm}$ wide, with an elongated, posteriorly tapering body, and a prominent head collar armed with 23 collar spines arranged in a single uninterrupted row. The posterior testis of $A$. shinanense was longitudinally elongated, which is similar to Acanthoparyphium spinulosum Johnston, 1917 but unique from the other closely related species, including Acanthoparyphium tyosenense Yamaguti, 1939, Acanthoparyphium kurogamo Yamaguti, 1939, and Acanthoparyphium marilae Yamaguti, 1934. The eggs of $A$. shinanense were larger than those of $A$. spinulosum, and the anterior extent of 2 lateral groups of vitellaria was slightly more limited in $A$. shinanense than in $A$. spinulosum. Molecular analysis of nuclear and mitochondrial genes revealed low homology with $A$. spinulosum from USA (96.1\% in 5.8S rRNA) and Ukraine (97.9\% in $28 \mathrm{~S}$ rRNA), Acanthoparyphium n. sp. from USA (98.0\% in 28S rRNA), and Acanthoparyphium sp. from Australia, Kuwait, and New Zealand. Biological characteristics, including its first intermediate host and natural definitive hosts, as well as its zoonotic capability, should be elucidated.
\end{abstract}

Key words: Acanthoparyphium shinanense n. sp., chick, intestinal fluke, brackish water clam, 5.8S rRNA, 28S rRNA, cox1, Republic of Korea

\section{INTRODUCTION}

The family Echinostomatidae Looss, 1899 (Digenea) is a group of intestinal parasites of predominantly birds, but also of mammals, including humans [1-3]. They are morphologically characterized by the presence of a head collar equipped with variable numbers and arrangements of collar spines [1-3]. At least 23 species have been reported to be able to infect humans; they include 8 species of Echinostoma, 2 species of Isthmiophora, 6 species of Echinochasmus, 3 species of Artyfechinostomum, and 1 species each of Acanthoparyphium, Echinoparyphium, Himasthla, and Hypoderaeum [1,3].

\footnotetext{
- Received 15 July 2021, revised 28 July 2021, accepted 28 July 2021.

*Corresponding author (cjy@snu.ac.kr)

(c) 2021, Korean Society for Parasitology and Tropical Medicine

This is an Open Access article distributed under the terms of the Creative Commons Attribution Non-Commercial License (https://creativecommons.org/licenses/by-nc/4.0) which permits unrestricted non-commercial use, distribution, and reproduction in any medium, provided the original work is properly cited.
}

Flukes of the genus Acanthoparyphium Dietz, 1909 are parasitic in aquatic birds of marine or brackish water in Tunisia, the Republic of Korea (=Korea), Japan, Australia, New Zealand, USA, Taiwan, the Philippines, Kuwait, and Ukraine [412]. At least 19 species have been described in this genus (see Discussion), although 4 of them were suggested to be synonyms of Acanthoparyphium spinulosum Johnston, 1917, which was originally described from Australia [13]. Later, A. spinulosum was reported from Australia again [6] and in Japan [4], Taiwan [14], USA [7,15-17], Kuwait [18], and Ukraine [19]. The type and oldest species is Acanthoparyphium phoenicopteri (Lühe, 1898) Dietz, 1909 described from the Tunisian flamingo Phenicopterus roseus at Tunis $[20,21]$. In addition, it should be noted that based on molecular analyses several species-undetermined but genetically distinct Acanthoparyphium flukes (Acanthoparyphium sp.) have been reported from New Zealand [12], USA [19], Australia [22], and Kuwait (GenBank, unpublished). 
In Korea, 2 species, Acanthoparyphium tyosenense Yamaguti, 1939 and Acanthoparyphium marilae Yamaguti, 1934, have been found $[9,11]$. In Japan, 6 species, including Acanthoparyphium charadrii Yamaguti, 1939 (synonymized with A. spinulosum by Soota et al. [23]), Acanthoparyphium kurogamo Yamaguti, 1939, A. marilae, Acanthoparyphium melanittae Yamaguti, 1939, Acanthoparyphium spinulosum suzugamo Yamaguti, 1939 (synonymized with A. spinulosum by Skrjabin and Bashkirova [24]), and Acanthoparyphium squatarolae Yamaguti, 1934 have been described [4,5]. In China, Acanthoparyphium loborchis Wang, 1977 and Acanthoparyphium haematopi Ku and Chiu, 1979 were described [25]. To date, only 1 species, A. tyosenense was reported to infect humans, involving 10 cases from 2 coastal villages of Puan-gun in Korea [9].

In the present study, we discovered a new group of Acanthoparyphium metacercariae having 23 collar spines from 2 species of brackish water clams, Ruditapes philippinarum and Coecella chinensis, on Aphae-do Island in Shinan-gun (County), Korea. The metacercariae were experimentally fed to chicks, and juveniles and adult flukes were recovered at days 5 and 7 postinfection, respectively. They were morphologically analyzed, and several points distinct from the pre-existing species, including A. spinulosum, A. marilae, and A. tyosenense, were recognized. We also performed molecular analysis, including sequencing of nuclear $5.8 \mathrm{~S}$ and $28 \mathrm{~S}$ rRNAs and mitochondrial cytochrome $c$ oxidase 1 ( $\operatorname{cox} 1$ ) genes. We concluded that our specimens are morphologically and molecularly unique from the pre-existing species, and here we propose our specimens as Acanthoparyphium shinanense n. sp.

\section{MATERIALS AND METHODS}

\section{Surveyed area and clam collection}

The surveyed area was a southwestern coastal region of Korea, i.e., Daecheon-ri (Village), Aphae-myon (Township), Shinan-gun, Jeollanam-do (Province) (latitude: 34.842; longitude: 126.274) (Fig. 1). The Manila clam, R. philippinarum (Fig. $2 \mathrm{~A})$, about 1,000 in number, and the Chinese wedge clam $C$. chinensis (Fig. 2B), 987 in number, were collected from the estuary of the surveyed area in August 2020. They were quickly transported to the laboratory of Institute of Parasitic Diseases, Korea Association of Health Promotion, Seoul, Korea. After species identification, the clams were individually opened with a knife. Each of the animal part of the clam was chopped into around 10 pieces in a petri dish, and the chopped samples

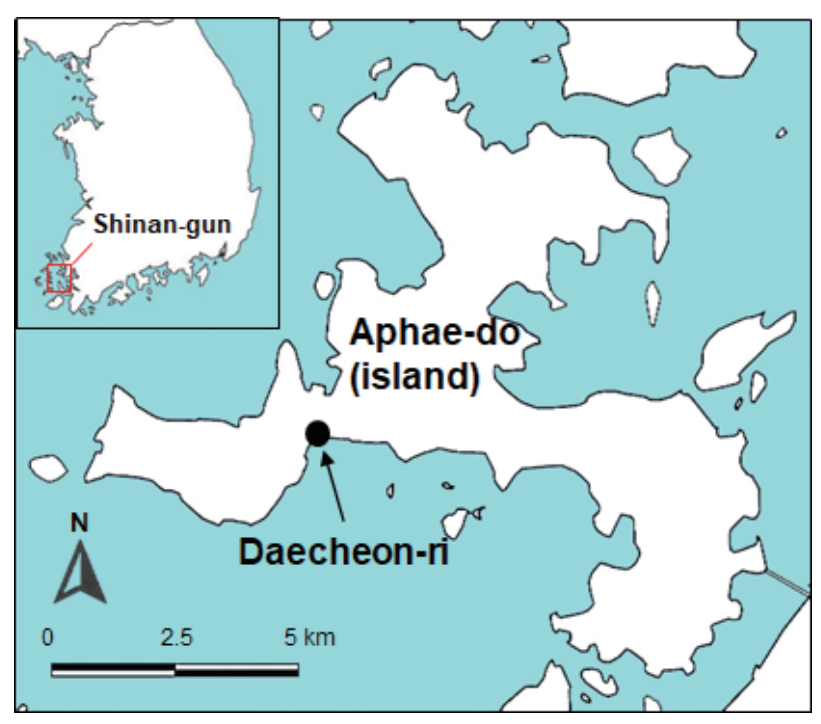

Fig. 1. Map showing the surveyed area (arrow) on Aphae-do (Island), Shinan-gun (County), Jeollanam-do (Province), Republic of Korea where the 2 species of brackish water clams were collected.

were pulverized for a short time (3 sec) using an electronic blender. The pulverized specimens were filtered through a thin layer of gauze, and $0.85 \%$ saline was added. Larval trematodes, in particular, metacercariae, were collected in a petri dish using a stereomicroscope.

\section{Morphological observations of metacercariae and experimental infection to chicks}

The metacercariae in the petri dish were morphologically examined using a stereomicroscope and transferred onto a glass slide with a cover slip for light microscopic examinations. The metacercariae were tentatively identified according to their general morphological features, in particular, the morphology of the head collar and collar spines. Two hundred metacercariae were administered orally to each of 5 experimental chicks (Gallus domesticus), 3-day-old or 7-day-old, and the chicks were killed by cervical dislocation at day 5 or day 7 post-infection. Their small intestines were resected, opened longitudinally in a petri dish containing $0.85 \%$ saline, and searched for worms using a stereomicroscope. The animal experiment followed the Institutional Guidelines for Animal Care and User Committee, Institute of Parasitic Diseases, Korea Association of Health Promotion, Seoul, Korea.

\section{Morphological observations of juvenile and adult flukes}

The juvenile (5-day-old) and adult flukes (7-day-old) were fixed in $10 \%$ formalin under a coverslip pressure for morpho- 

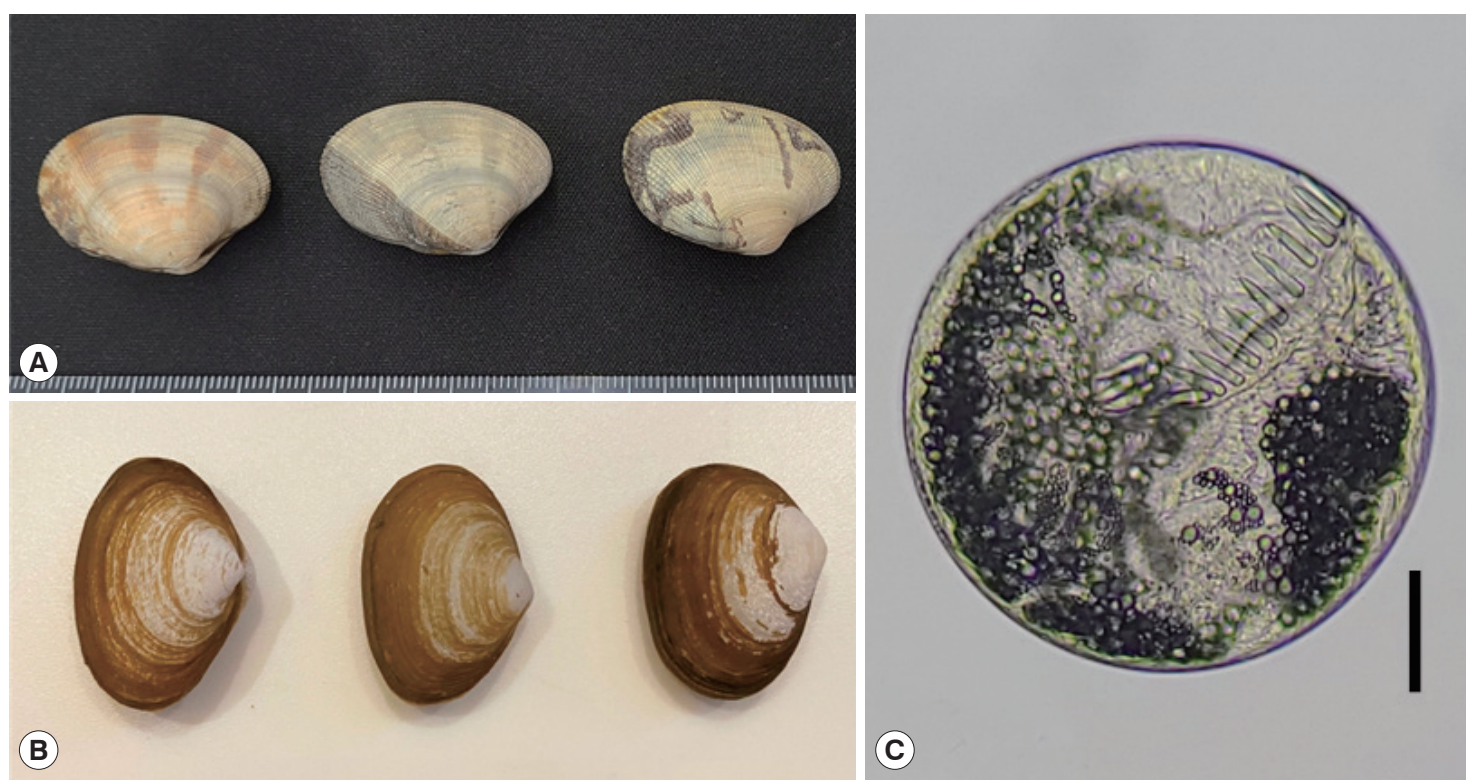

Fig. 2. Intermediate host and a metacercaria of Acanthoparyphium shinanense n. sp. (A) Ruditapes philippinarum (the Manila clam) with various morphologies. (B) Coecella chinensis (the Chinese wedge clam) showing minor variation in morphology. (C) Metacercaria encysted with a thin shell, round, showing an oral sucker armed with collar spines $(n=23)$ and excretory bladder with excretory granules. Bar $=0.05 \mathrm{~mm}$.

logical studies. Some specimens were preserved in $70-80 \%$ ethanol for molecular analyses. The formalin-fixed samples were washed in water, stained with Semichon's acetocarmine, dehydrated in a graded series of ethanol, cleared in xylene, and mounted in Canada balsam. To keep the morphology of intrauterine eggs finely visible, some acetocarmine-stained samples in $70 \%$ ethanol were cleared in glycerin-alcohol and mounted in glycerin jelly. Twelve acetocarmine-stained and glycerin jelly-mounted specimens were used for morphological observations and measurements. They were compared with other Acanthoparyphium spp. based on morphological characteristics suggested by previous authors (Table 1$)[4,5,7,9,13]$. The photos of adult flukes were taken with an Olympus DP72 digital camera (Tokyo, Japan) on an Olympus CKX41 microscope (Tokyo, Japan). The size of organs and structures were measured from digital images using 'cellSens standard v1.5 image analysis software' (Leica, Wetzlar, Germany).

\section{Molecular genetic analysis}

The adult flukes preserved in 70-80\% ethanol were further processed for molecular analysis. Genomic DNA was extracted from adult specimens according to the spin-column protocol described for DNeasy ${ }^{\circledR}$ Blood \& Tissue kit (QIAGEN, Hilden, Germany). Nuclear 5.8S rRNA and 28S rRNA genes and mitochondrial cytochrome $c$ oxidase 1 ( $c 0 x 1)$ gene were amplified by PCR on a C1000 Touch Thermal Cycler according to the procedure reported previously $[17,26,27]$. The forward and reverse primers for 5.8S rRNA were BDI-ITS_F (5'-GTC GTA ACA AGG TTC CGT A-3') and 4S-ITS_R (5'-TCT AGA TGC GTT CGA AGT GTC GAT G-3'), respectively [17], and the primers for 28S rRNA were dig12_F (5'-AAG CAT ATC ACT AAG CGG$3^{\prime}$ ) and Lo_R (5'-GCT ATC CTG AGR GAA ACT TCG-3') [26]. The primers for cox 1 were JB3_F (5'-TTT TTT GGG CAT CCT GAG GTT TAT-3') and trem.cox1.rrnl_R (5'-AAT CAT GAT GCA AAA GGT A-3') [27]. The basic local alignment search tool (BLAST; http://blast.ncbi.nlm.nih.gov/Blast.cgi) was used to assess the genetic identity of the samples. The sequence obtained using Geneious ${ }^{\circledR}$ version 11.1.5 (Biometers Ltd., Auckland, New Zealand) was compared with the GenBank reference sequences of the Acanthoparyphium species or other Echinostomatidae family members. The phylogenetic trees were constructed using the maximum-likelihood method based on Tamura-Nei model of nucleotide substitution with 1,000 bootstrap replications with our samples and others deposited in GenBank and viewed by MEGA-X program.

\section{RESULTS}

Infection status of $A$. shinanense metacercariae in clams About 2,000 A. shinanense metacercariae were harvested 
Table 1. Measurements of Acanthoparyphium shinanense n. sp. (adults) in comparison with other Acanthoparyphium species (unit: $\mu$ m)

\begin{tabular}{|c|c|c|c|c|c|}
\hline \multirow{2}{*}{ Species } & \multirow{2}{*}{$\begin{array}{l}\text { Acanthoparyphium } \\
\text { shinanense n. sp. } \\
\text { (Present study) }\end{array}$} & \multicolumn{2}{|c|}{ Acanthoparyphium spinulosum } & \multicolumn{2}{|c|}{ Acanthoparyphium tyosenense } \\
\hline & & Johnston [13] & Martin and Adams [7] & Yamaguti [5] & Chai et al. [9] \\
\hline No. of specimens measured & $(n=12)$ Range (Mean) & $(n=2)$ Range & $(n=20)$ Range (Mean) & $(n=10)$ Range & $(n=10)$ Range (Mean) \\
\hline Body length (BL) & $2,885-3,551(3,176)$ & 5,550 & $3,320-5,530(4,090)$ & $2,450-3,850$ & $2,480-3,130(2,830)$ \\
\hline Body width (BW) & $606-847(683)$ & 800 & $600-1,220(830)$ & $500-750$ & $520-730(630)$ \\
\hline Ratio of BL/BW & 4.65:1 & $6.94: 1$ & $4.93: 1$ & - & 4.49:1 \\
\hline Head collar length (CL) & $199-252(228)$ & $252^{\mathrm{a}}$ & $220^{\mathrm{a}}$ & $164^{\mathrm{a}}$ & $164^{a}$ \\
\hline Head collar width (CW) & $332-434(388)$ & 407 & $366^{a}$ & $230-300$ & $250-300(270)$ \\
\hline Oral sucker length (OSL) & $94-141(117)$ & 155 & $121^{a}$ & $93-110$ & $90-110(100)$ \\
\hline Oral sucker width (OSW) & $93-171(133)$ & 145 & $103-165(127)$ & $109^{a}$ & $93^{a}$ \\
\hline Angle spine length (ASL) & $54-72(64)$ & $47^{a}$ & $50-72(63)$ & $39-54$ & $50^{\mathrm{a}}$ \\
\hline Angle spine width (ASW) & $15-20(18)$ & $19^{a}$ & $12-22(17)$ & 9-12 & $11^{\mathrm{a}}$ \\
\hline Lateral spine length (LSL) & $67-78(72)$ & 75 & - & - & $54^{a}$ \\
\hline Lateral spine width (LSW) & $16-21(18)$ & 16 & - & - & $11^{\mathrm{a}}$ \\
\hline Dorsal spine length (DSL) & $53-73(65)$ & - & - & - & - \\
\hline Dorsal spine width (DSW) & 15-21 (19) & - & - & - & - \\
\hline Prepharynx length (PL) & $117-159(137)$ & $81^{\mathrm{a}}$ & $0-90$ & - & - \\
\hline Pharynx length (PHL) & $97-150(121)$ & 133 & $93-137(113)$ & $84-108$ & 80-100 (90) \\
\hline Pharynx width (PHW) & $61-104(76)$ & 107 & 59-131 (92) & $57-80$ & $60-90(70)$ \\
\hline Esophagus length (EL) & $228-440$ (344) & 388 & $373-700$ (493) & $300-450$ & $170-280(220)$ \\
\hline Cirrus sac length (CSL) & $812-1,217(965)$ & - & $558-1134(825)$ & $550-880$ & $780^{\mathrm{a}}$ \\
\hline Cirrus sac width (CSW) & 83-180 (114) & - & 70-196 (127) & $120-190$ & $140^{\mathrm{a}}$ \\
\hline Seminal vesicle length (SVL) & $96-234(161)$ & $168^{a}$ & $122^{\mathrm{a}}$ & - & - \\
\hline Seminal vesicle width (SWM) & $61-153(82)$ & $168^{\mathrm{a}}$ & $97^{a}$ & - & - \\
\hline Ventral sucker length (VSL) & $383-458(407)$ & 582 & $342-473(388)$ & $300-375$ & $240-320(290)$ \\
\hline Ventral sucker width (VSW) & $353-424(390)$ & 543 & $351-535(413)$ & $355^{\mathrm{a}}$ & $291^{a}$ \\
\hline Ovary length (OVL) & $92-153(123)$ & 194 & $115-230(164)$ & $110-150$ & $110-140(120)$ \\
\hline Ovary width (OWW) & $111-155(133)$ & 136 & $109-205$ (153) & $150-200$ & $130-180(150)$ \\
\hline Mehlis' gland length (MEL) & 63-132 (93) & - & $122^{\mathrm{a}}$ & - & $185^{\mathrm{a}}$ \\
\hline Mehlis' gland width (MEW) & 189-326 (265) & - & $170^{\mathrm{a}}$ & - & $344^{\mathrm{a}}$ \\
\hline Ant. testis length (ATL) & 226-375 (315) & 582 & $340-644$ (410) & $270-400$ & $260-330(290)$ \\
\hline Ant. testis width (ATW) & 275-377 (322) & 542 & $240-532(360)$ & $275-450$ & $310-390(350)$ \\
\hline Ratio of ATL/ATW & 0.98:1 & $1.07: 1$ & $1.13: 1$ & - & $0.83: 1$ \\
\hline Post. testis length (PTL) & $303-483(380)$ & 776 & $460-756(535)$ & $368^{a}$ & $320-370(340)$ \\
\hline Post. testis width (PTW) & $200-290(252)$ & 542 & $196-560(294)$ & $355^{\mathrm{a}}$ & $290-380(340)$ \\
\hline Ratio of PTL/PTW & $1.51: 1$ & $1.43: 1$ & $1.81: 1$ & $1.04: 1^{\mathrm{a}}$ & $1: 01$ \\
\hline Forebody length (FORE) & $503-733(646)$ & $883^{a}$ & $952^{\mathrm{a}}$ & $681^{a}$ & $450^{a}$ \\
\hline ODIV & $482-687(601)$ & $799^{a}$ & $726^{a}$ & $586^{a}$ & $371^{a}$ \\
\hline OVAR & $115-271(180)$ & $420^{\mathrm{a}}$ & $369^{a}$ & $368^{a}$ & $476^{a}$ \\
\hline TEND & $850-1,110(969)$ & $2,186^{\mathrm{a}}$ & $1,262^{\mathrm{a}}$ & $927^{a}$ & $768^{\mathrm{a}}$ \\
\hline OSW/PHW & $1.2-2.3(1.8)$ & $1.4^{\mathrm{a}}$ & $1.4^{\mathrm{a}}$ & - & $1.3^{\mathrm{a}}$ \\
\hline BW/BL (\%) & 19-26 (22) & $14^{a}$ & $20^{\mathrm{a}}$ & - & $22^{\mathrm{a}}$ \\
\hline FORE/BL (\%) & $17-24(20)$ & $16^{a}$ & $23^{a}$ & - & $16^{a}$ \\
\hline CW/BW (\%) & 699-966 (822) & $1,364^{\mathrm{a}}$ & $1,118^{\mathrm{a}}$ & - & $1,048^{a}$ \\
\hline ODIV/BL (\%) & $16-23(19)$ & $14^{\mathrm{a}}$ & $18^{a}$ & - & $13^{a}$ \\
\hline OVAR/BL (\%) & 4-8 (6) & $8^{a}$ & $9^{a}$ & - & $17^{a}$ \\
\hline TEND/BL (\%) & 27-34 (31) & $39.4^{a}$ & $31^{a}$ & - & $27^{a}$ \\
\hline Egg length & 95-111 (103) & 85 & 84-106 (96) & $84-110$ & $105-111(108)$ \\
\hline Egg width & 62-71 (66) & 69 & $56-68$ (64) & $60-69$ & $55-63(59)$ \\
\hline
\end{tabular}

ODIV, distance from anterior extremity to intestinal bifurcation; OVAR, distance from the posterior margin of ventral sucker to ovary; TEND, length of post-testicular region.

${ }^{a}$ Estimated from the original drawing of the worm in each reference. 
from a total of $1,000 R$. philippinarum clams examined. Whereas, only 100 metacercariae of the same species were obtained from 987 C. chinensis clams examined. The clams were pooled in groups of 10 in number, and all (100\%) of 100 groups of $R$. philippinarum were found infected, whereas only 10 (10.1\%) of 99 groups of $C$. chinensis clams were infected with the metacercariae. The localities of the metacercariae in the clams were the foot muscle, gill, and mantle.

\section{Recovery of $A$. shinanense worms from experimental chicks}

From 2 chicks sacrificed at day 5 post-infection, total 34 juvenile flukes (13 and 21 , respectively) were harvested from their small intestines, with the average recovery rate of $8.5 \%$. Also, from 3 chicks sacrificed at day 7 post-infection, total 104 adult flukes were recovered $(22,33$, and 49 specimens, respectively), showing the average recovery rate of $17.3 \%$. The overall worm recovery rate from 5 chicks was $13.8 \%$. All of the 5-dayold juvenile flukes were immature without uterine eggs, whereas the 7-day-old adult flukes were fully matured containing a number of uterine eggs.

\section{Description of worms}

Acanthoparyphium shinanense n. sp. (Table 1; Figs. 2C, 3A-F)

Family: Echinostomatidae Looss, 1899

Subfamily: Himasthlinae Odhner, 1910

Genus: Acanthoparyphium Dietz, 1909

Metacercaria (Fig. 2C): Metacercariae oval to round, covered with a thin wall, and $0.216(0.203-0.226) \mathrm{mm}$ in average diameter $(\mathrm{n}=10)$. Oral and ventral suckers plainly visible. Head collar equipped with total 23 collar spines uninterrupted dorsally and without corner spines distinctly seen around the oral sucker. Excretory tubules containing small round excretory granules distributed extensively in the anterior and posterior fields of the body.

When the metacercariae were excysted applying gentle pressure on a coverslip, the presence of a head collar with characteristic arrangement of collar spines around the oral sucker was then better visualized.

Adult (Table 1; Fig. 3A-F): Body dorsoventrally flattened, elongated leaf-like with slightly attenuated anterior end and more or less tapered posterior end, 3.18 (2.89-3.55) $\mathrm{mm}$ in length and 0.68 (0.61-0.85) $\mathrm{mm}$ in maximum width at uterine or ovarian level $(\mathrm{n}=12)$ (Fig. 3A-C). Tegument beset with triangular spines, becoming less dense posteriorly, extending to level of uterus or anterior testis. Forebody long representing about $20.4 \%$ of whole body length. Anterior end characteristically equipped with an oral sucker and a prominent head collar. Oral sucker subterminal, small and spherical, muscular, about $1 / 3.5$ of the size of the ventral sucker. Head collar small but prominent, reniform, and muscular, armed with a single row of collar spines (Fig. 3D-F). Collar spines 23 in total, without dorsal interruption, with the formula of 3-3-4-3-4-3-3, including ventral spines $3+3$, lateral spines $3+3$, and dorsal spines $4+3+4$, without corner spines (Fig. 3 F). Collar spines relatively short in length, moderately broad, with sharp-pointed ends (Fig. 3D, E). The innermost ventral collar spines on each side slightly smaller than the other 21 collar spines. Prepharynx short; pharynx muscular, elongated. Esophagus relatively long; intestinal bifurcation at about $10 \%$ of total body length; ceca narrow, blind, overlapped by vitelline follicles, ending nearby the posterior termination of vitelline follicles. Cirrus sac elongated, reaching back far beyond the posterior end of ventral sucker, up to about halfway between ventral sucker and ovary. Terminal part of cirrus armed with tiny spines with a broad base. Seminal vesicle thin-walled, elongated or coiled, containing sperms and connected to muscular and tubular pars prostatica, ejaculatory duct, and a long cirrus armed with small spines on its surface. Genital atrium with genital pore median, just in front of ventral sucker, receiving female (metraterm) and male reproductive (ejaculatory) duct. Metraterm weakly muscular, connected to genital pore. Uterus intercecal, short, between ventral sucker and anterior testis, containing a small number $(n=33-75)$ of eggs. Ovary spherical or transversely elliptical, median or slightly submedian, almost equatorial, between seminal vesicle and Mehlis' gland. Mehlis' gland diffuse, dorsal, median, larger than ovary, connected to ovary and uterine tubule. Uterine seminal receptacle present; Laurer's canal present. Vitelline follicles extensive, extending laterally forming 2 lateral groups, from near posterior extremity up to the level of anterior margin of anterior testis or rarely Mehlis' gland; the 2 groups of vitellaria not merge near posterior end of body. Two testes post-equatorial, tandem, entire, with smooth surface, almost adjacent to each other. Anterior testis globular, and posterior testis usually slightly elongated. Eggs not numerous, yellowish, oval to ovoid, immature containing a germ cell, with a small, inconspicuous operculum, and a small abopercular thickening or wrinkling at the abopercular end, 0.103 (0.095-0.111) mm long and 66 (62-71) $\mathrm{mm}$ wide $(\mathrm{n}=60)$. Excretory vesicle Y-shaped, bifurcates just 

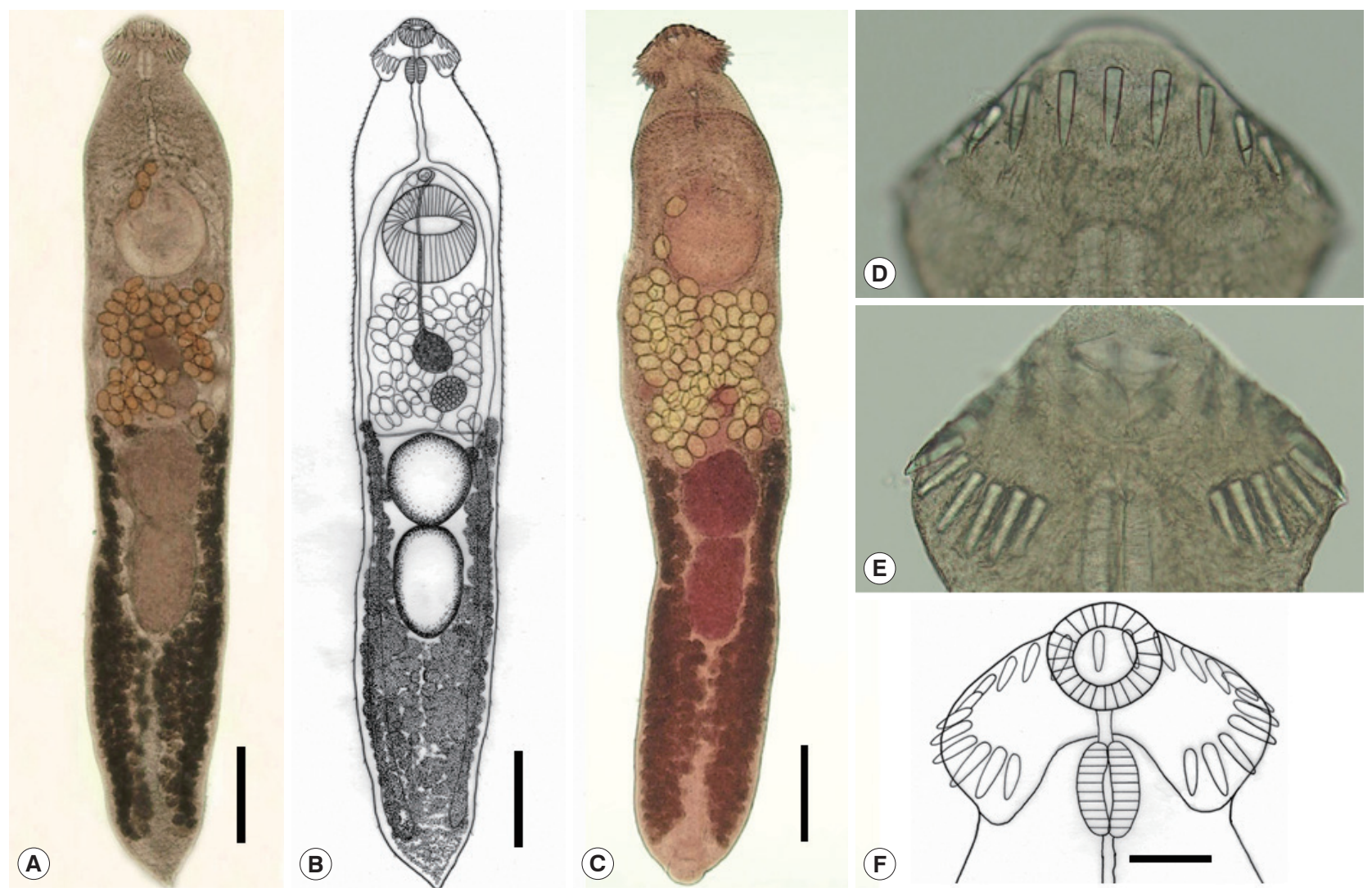

Fig. 3. Whole adult worms and the head collar of Acanthoparyphium shinanense n. sp. Ventral views. (A) Unstained specimen recovered from an experimental chick infected with the metacercariae at day 7 post-infection. Note the level of vitellaria distribution, longitudinally elongated posterior testis, and tapering posterior extremity. Bar $=0.35 \mathrm{~mm}$. (B) Line drawing of the worm in Fig. 3A. Bar=0.35 mm. (C) Another adult specimen stained with Semichon's acetocarmine followed by clearing in glycerin alcohol and mounting in glycerin jelly to maintain the morphology of organs and structures, especially the uterine eggs. Bar $=0.35 \mathrm{~mm}$. (D) Head collar with dorsal and lateral collar spines (unstained). (E) Head collar with lateral and ventral spines (unstained). (F) Line drawing of the head collar and collar spines. Note that the spines are in a single row without end group spines and dorsally uninterrupted. The terminal spine on each side is the smallest. Bar $=0.05 \mathrm{~mm}$.

posterior to posterior testis; excretory pore terminal.

\section{Taxonomic summary}

- Type host: Gallus domesticus (chick, experimental)

- Site of infection: Small intestine

- Type locality: Daecheon-ri (Village), Aphae-myon (Township; Aphae-do Island), Shinan-gun (County), Jeollanam-do (Province), Republic of Korea

- Deposition of specimens: The specimens are deposited in the Parasite Museum, Institute of Parasitic Diseases, Korea Association of Health Promotion, Seoul, Korea (no. 2021-001101, holotype, and no. 2021-0011-02 10, paratypes). Voucher specimens are also deposited in Meguro Parasitological Museum, Tokyo, Japan (MPM Coll. No. 21773).

- Etymology: The specific name refers to the name of the lo- cality of the type specimen, Shinan-gun, where the infected brackish water clams were collected.

\section{Molecular analyses}

The amplification of 5.8S rRNA, 28S rRNA, and cox 1 genes of our samples produced partial sequences of 459-460 bp, 754-1,134 bp, and 451 bp, respectively. The phylogenetic tree for $5.8 \mathrm{~S}$ rRNA was established based on sequences of our samples, i.e., 1 isolate (MZ396401) from metacercariae in C. chinensis clams and 5 (MZ396396-396400) from adult flukes obtained from experimental chicks infected with metacercariae from $R$. philippinarum clams, in comparison with other members of the Echinostomatidae, including A. spinulosum from USA (KM880017) and Acanthoparyphium spp. from Australia (MH257759) and New Zealand (KJ956378, KJ956379, KJ 


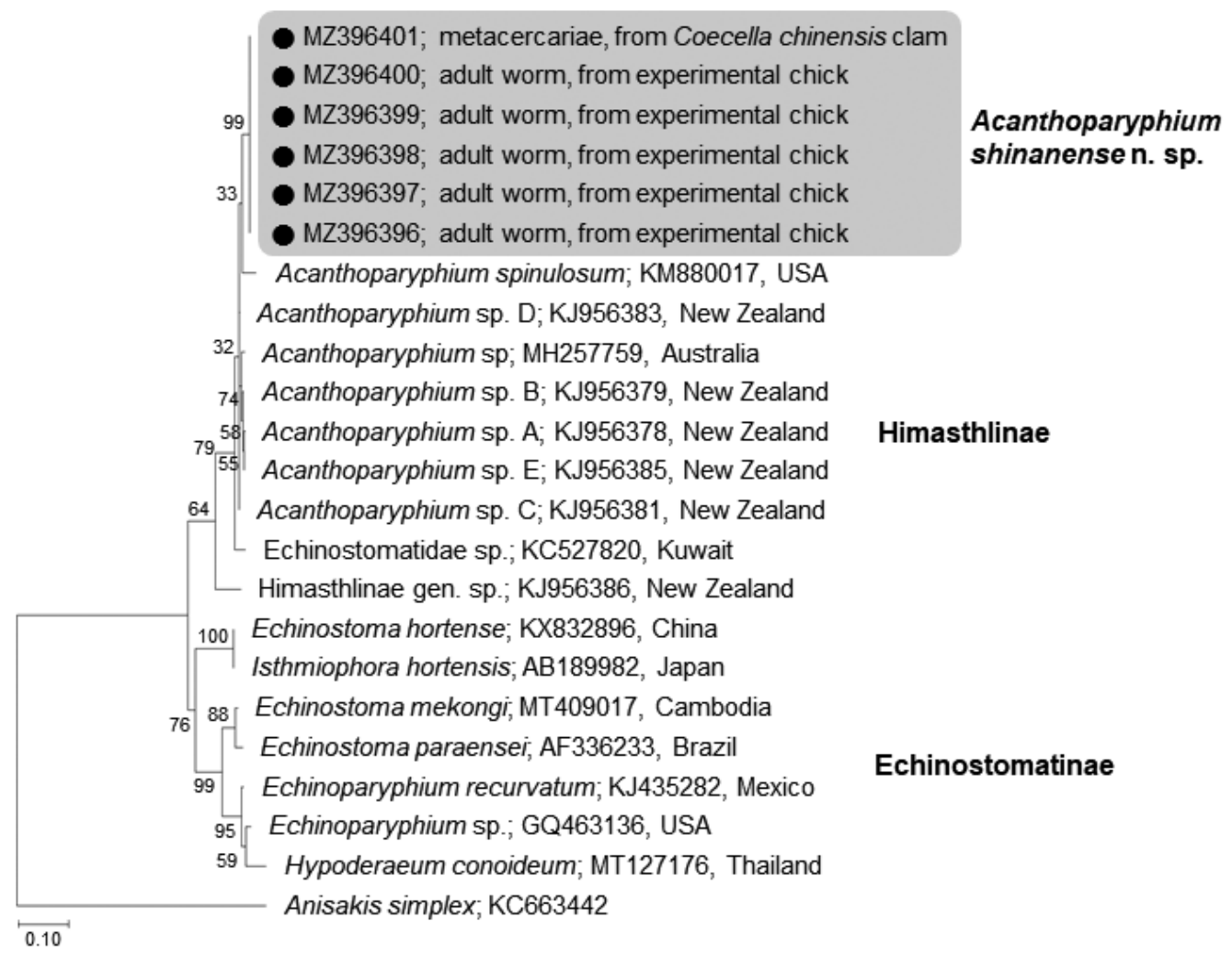

Fig. 4. A phylogenetic tree inferred from 5.8S rRNA sequences of Acanthoparyphium shinanense $\mathrm{n}$. sp. in relation with $A$. spinulosum, Acanthoparyphium sp., and other members of the Himasthlinae and Echinostomatinae constructed using the maximum-likelihood method. •: our specimens.

956381, KJ956383, KJ956385) (Fig. 4). The sequences of our samples $(\mathrm{n}=6)$ were clustered together $(100 \%$ homologous $)$ with high bootstrap values and constituted a new lineage distinct from other Echinostomatidae registered in GenBank (Fig. 4; Table 2). Our samples revealed low homologies with A. spinulosum from USA (96.1\%), Acanthoparyphium sp. from Australia (96.6\%) and New Zealand (97.0-97.9\%) (Table 2).

The phylogenetic tree for $28 \mathrm{~S}$ rRNA was established based on our samples, i.e., 1 isolate (MZ146324) from metacercariae in clams and 5 (MZ146319-146323) from experimentally obtained adult flukes in comparison with 24 species of the Echinostomatidae, including A. spinulosum from Ukraine (KT956939) and Acanthoparyphium sp. from Australia (MH257769) and USA (KT956940) (Fig. 5). The sequences of our samples $(n=6)$ were clustered together (100\% homologous) with high bootstrap values and constituted a new lineage distinct from other Echinostomatidae registered in GenBank (Fig. 5; Table 2). Our samples showed low homologies with A. spinulosum from Ukraine (97.9\%), Acanthoparyphium n. sp. from USA (98.0\%), Acanthoparyphium sp. from Australia (98.1\%), and Himasthla spp. from Ukraine or USA (94.3-95.9\%) (Table 2).

The phylogenetic tree for cox 1 was established based on sequences of our samples, i.e., 1 isolate (MZ396463) from metacercariae in clams and 4 (MZ396459-396462) from adult flukes obtained from experimental chicks, in comparison with other members of the Echinostomatidae, including Acanthoparyphium spp. from New Zealand (FJ765464, KJ956255, KJ956279, KJ956288, KJ956289) and Kuwait (MG792058) (Fig. 6). The cox 1 sequences were highly variable depending on different species or isolates of Acanthoparyphium. The homology between adults ( 4 isolates) and a metacercaria (1 isolate) in our study was only $94.7 \%$. However, the 4 adult isolates exhibited $100 \%$ homology together (Table 2). The sequence homology between our samples and Acanthoparyphium sp. from New Zealand was only $84.0-86.9 \%$ and that between our samples and Acanthopariphium sp. from Kuwait was only 83.5-83.7\%.

\section{Remarks}

Compared with the 15 valid or 'need-to-evaluate' species of 
Table 2. Sequence comparison of our samples with other members of the Himasthlinae in GenBank based on 5.8S rRNA, 28S rRNA, and cox1 genes

\begin{tabular}{|c|c|c|c|c|c|}
\hline \multicolumn{2}{|c|}{ 5.8S rRNA region } & \multicolumn{2}{|l|}{ 28S rRNA region } & \multicolumn{2}{|l|}{$\operatorname{cox} 1$} \\
\hline $\begin{array}{l}\text { Between our isolates } \\
\text { (A. shinanense n. sp.) }\end{array}$ & 100 & & 100 & & $94.7-100$ \\
\hline $\begin{array}{l}\text { Acanthoparyphium sp. C } \\
\text { (KJ956381, New Zealand) }\end{array}$ & 97.9 & $\begin{array}{l}\text { Acanthoparyphium sp. } \\
\text { (MH257769, Australia) }\end{array}$ & 98.1 & $\begin{array}{l}\text { Acanthoparyphium sp. B } \\
\text { (KJ956279, New Zealand) }\end{array}$ & $86.7-86.9$ \\
\hline $\begin{array}{l}\text { Acanthoparyphium sp. D } \\
\text { (KJ956383, New Zealand) }\end{array}$ & 97.7 & $\begin{array}{l}\text { Acanthoparyphium n. sp. } \\
\text { (KT956940, USA) }\end{array}$ & 98.0 & $\begin{array}{l}\text { Acanthoparyphium sp. D } \\
\text { (KJ956288, New Zealand) }\end{array}$ & 86.7 \\
\hline $\begin{array}{l}\text { Acanthoparyphium sp. A } \\
\text { (KJ956378, New Zealand) }\end{array}$ & 97.0 & $\begin{array}{l}\text { Acanthoparyphium spinulosum } \\
\text { (KT956939, Ukraine) }\end{array}$ & 97.9 & $\begin{array}{l}\text { Acanthoparyphium sp. A } \\
\text { (KJ956255, New Zealand) }\end{array}$ & 85.6 \\
\hline $\begin{array}{l}\text { Acanthoparyphium sp. B } \\
\text { (KJ956379, New Zealand) }\end{array}$ & 97.0 & $\begin{array}{l}\text { Himasthla limnodromi } \\
\text { (KT956943, USA) }\end{array}$ & 95.9 & $\begin{array}{l}\text { Acanthoparyphium sp. C } \\
\text { (FJ765464, New Zealand) }\end{array}$ & $85.1-85.3$ \\
\hline $\begin{array}{l}\text { Acanthoparyphium sp. E } \\
\text { (KJ956385, New Zealand) }\end{array}$ & 97.0 & $\begin{array}{l}\text { Himasthla leptosoma } \\
\text { (KT956942, Ukraine) }\end{array}$ & 94.3 & $\begin{array}{l}\text { Acanthoparyphium sp. E } \\
\text { (KJ956289, New Zealand) }\end{array}$ & $84.0-84.8$ \\
\hline $\begin{array}{l}\text { Acanthoparyphium sp. } \\
\text { (MH257759, Australia) }\end{array}$ & 96.6 & $\begin{array}{l}\text { Himasthla militaris } \\
\text { (KT956944, Ukraine) }\end{array}$ & 94.3 & $\begin{array}{l}\text { Acanthoparyphium sp. } \\
\text { (MG792058, Kuwait) }\end{array}$ & $83.5-83.7$ \\
\hline $\begin{array}{l}\text { Acanthoparyphium spinulosum } \\
\text { (KM880017, USA) }\end{array}$ & 96.1 & & & & \\
\hline
\end{tabular}

Acanthoparyphium reported so far (Table 3), the new species differed from most of them $[5,9,23,24]$ in the body size and shape, sucker ratio, egg size, and the morphology of head collar, collar spines, testes, and the extent of vitellaria. A. phenicopteri, the type species, is much smaller in body size than the new species, with a broader head collar, smaller sucker ratio $(1 / 2)$, ventral sucker situated farther back in the body, and smaller number of uterine eggs [28]. A. haematopi [25] is differed from the new species in the remarkably smaller egg size, 0.073-0.082 $\mathrm{mm}$ in length, and the extent of the vitellaria. A. loborchis and Acanthoparyphium ochthodromi Tubangui, 1933 have 2 lobulated testes with irregular margins [25] unlike the new species. Acanthoparyphium pagollae Cable et al., 1960 [29] differs from the new species in the extent of vitellaria, up to the level anterior to the ovary in the former but limited up to the level of anterior border of anterior testis in the latter. Acanthoparyphium macracanthum Rybakov and Lukomskaya, 1988 has a small, plump or stout body with 2 transversely elongated testes [30], which is markedly different from the new species. Acanthoparyphium paracharadrii Velasquez, 1964 has much smaller body and egg sizes, 1.39-1.91 mm and 0.071-0.079 mm in length, respectively, and is unique having a very small cirrus sac [31]. Acanthoparyphium lobatum Soota et al., 1970 [32] has 26-28 collar spines that is not consistent with the generic characteristic of Acanthoparyphium and has 2 deeply branched testes which is a markedly different feature from the new species. Acanthoparyphium jeetai Chakrabarti, 1972 [33] reported from a bird in India needs further evaluation.

A. squatarolae Yamaguti, 1934 is differed from the new spe- cies in that the former has a less extended vitellaria up to the level of the anterior extremity of the posterior testis and has 2 globular testes [4]. Also, A. marilae Yamaguti, 1934 differs from the new species in that the former has a much less extended vitellaria up to the level beyond the posterior margin of the posterior testis and has 2 globular testes [4]. A. tyosenense Yamaguti, 1939 has a rounded posterior end and 2 globular testes [5], whereas the new species has a tapering posterior end and 1 globular and 1 longitudinally elongated testes. A. kurogamo Yamaguti, 1939 is differed from the new species in the position of the ventral sucker and testes (located more posteriorly) and having 2 globular testes [5]. A. melanittae Yamaguti, 1939 has an extremely anterior extension of the vitellaria up to the level of the ventral sucker and has 2 globular testes [4].

The new species is morphologically very close to A. spinulosum Johnston, 1917 in the body size and shape and the longitudinally elongated shape of the posterior testis [13]. However, the egg size of A. spinulosum was smaller than the new species, $0.085 \times 0.069 \mathrm{~mm}$ [13], 0.084-0.106 $\times 0.056-0.068 \mathrm{~mm}$ [7], or $0.085-0.100 \times 0.066-0.082 \mathrm{~mm}[14]$, compared to $0.095-$ $0.111 \times 0.062-0.071 \mathrm{~mm}$ in the new species. However, in another report [6], the egg size of A. spinulosum could be 0.092$0.100 \times 0.065-0.076 \mathrm{~mm}$, only slightly smaller than that of the new species. A significant finding was that the new species has vitellaria never extending anteriorly from the level of the anterior margin of the anterior testis or Mehlis' gland, whereas $A$. spinulosum has vitellaria extending up to the level of the anterior margin of the ovary [6,13] or the level of Mehlis' gland [7]. 


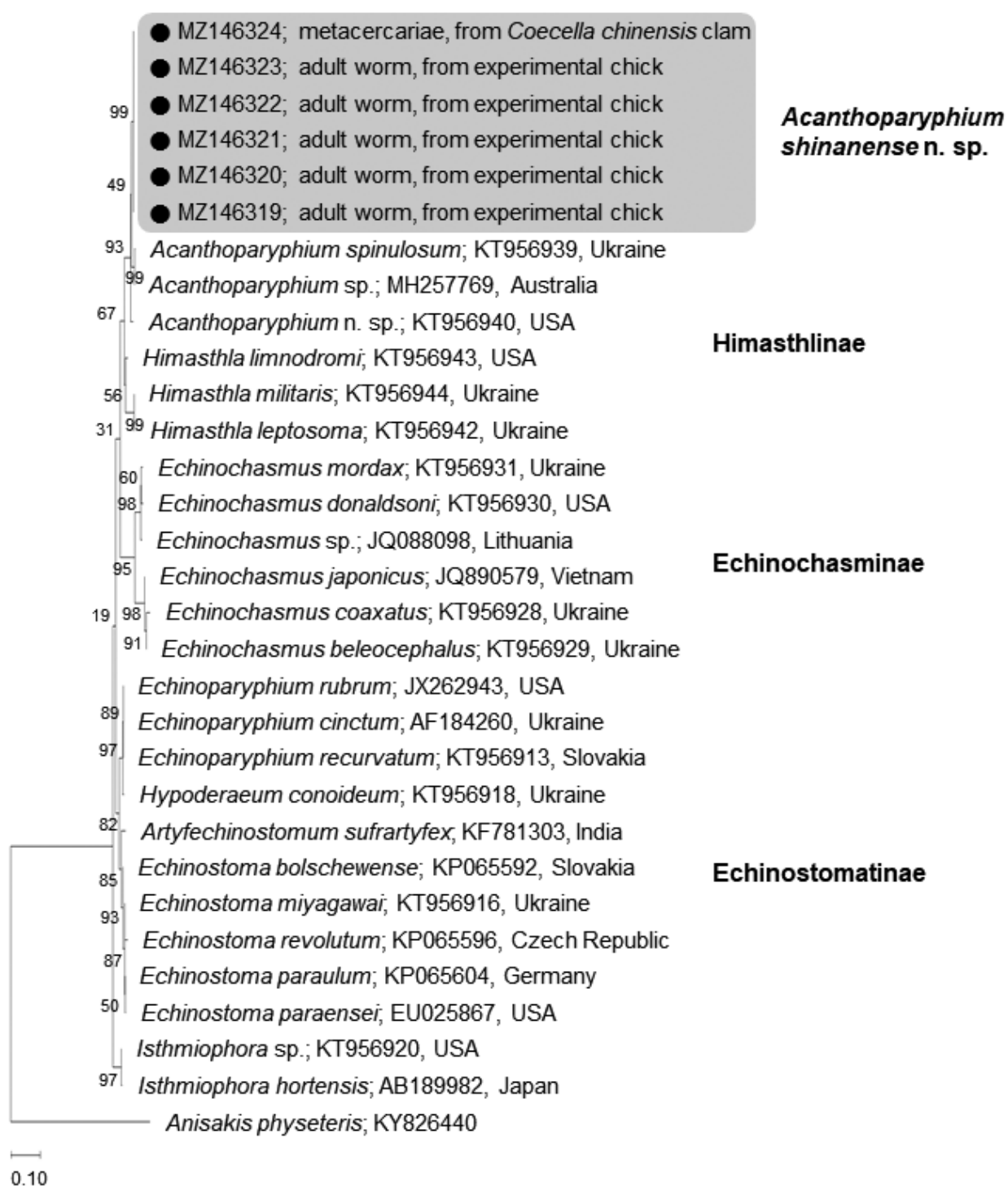

Fig. 5. A phylogenetic tree inferred from 28S rRNA sequences of Acanthoparyphium shinanense $\mathrm{n}$. sp. in relation with $A$. spinulosum, Acanthoparyphium sp., Acanthoparyphium n. sp., and other members of the Himasthlinae, Echinochasminae, and Echinostomatinae constructed using the maximum-likelihood method. $\bullet$ : our specimens.

The phylogenetic trees based on 5.8S rRNA, 28S rRNA, and cox 1 sequences revealed a unique lineage of our samples. The sequence homology based on $5.8 \mathrm{~S}$ rRNA between our samples and A. spinulosum from USA (KM880017) was $96.1 \%$ and that between our samples and Acanthoparyphium sp. from Australia (MH257759) was 96.6\%, relatively low and not enough for them to be identical. Similarly, the sequence homology based on $28 \mathrm{~S}$ rRNA between our samples and A. spinulosum from Ukraine (KT956939) was 97.9\%, that between our samples and Acanthoparyphium n. sp. from USA was $98.0 \%$, and that between our samples and Acanthoparyphium sp. from Australia
(MH257769) was 98.1\%, all of these figures are considered not enough for them to be identical. The sequence homology based on cox 1 gene between our samples and Acanthoparyphium sp. from Kuwait (MG792058) was 83.5-83.7\% and that between our samples and Acanthoparyphium sp. from New Zealand (FJ765464, KJ956255, KJ956279, KJ956288, KJ956289) was $84.0-86.9 \%$, indicating them to be far from identical. Nucleotide sequences of other Acanthoparyphium spp. reported morphologically are not yet available in GenBank. 


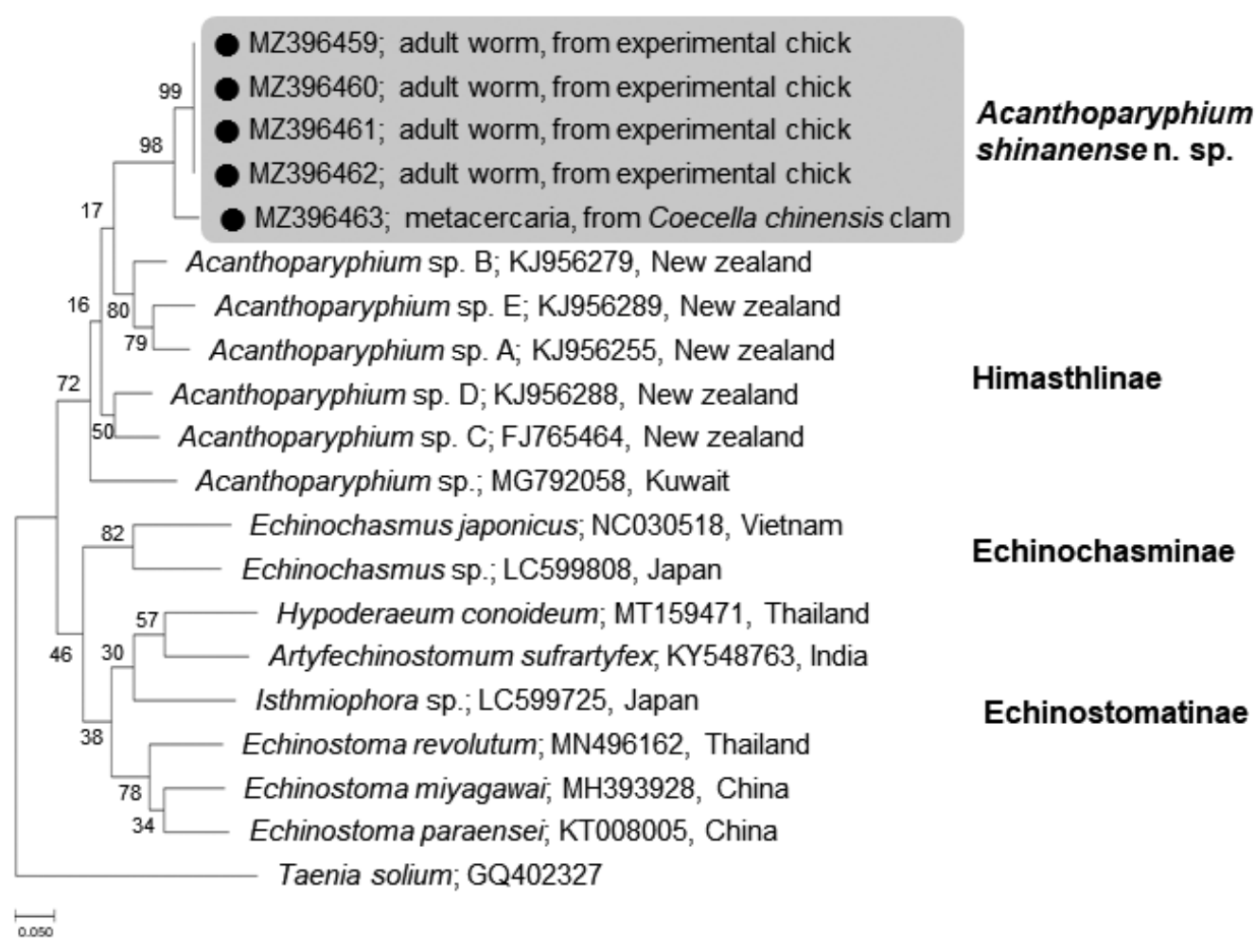

Fig. 6. A phylogenetic tree inferred from mitochondrial cytochrome c oxidase 1 (cox1) gene sequences of Acanthoparyphium shinanense n. sp. in relation with Acanthoparyphium sp. (Himasthlinae) and members of the Echinochasminae and Echinostomatinae constructed using the maximum-likelihood method. • : our specimens.

Table 3. Species of Acanthoparyphium reported among the literature

\begin{tabular}{lll}
\hline Species, nominator, year & Countries reported ${ }^{\text {a }}$ & Taxonomic validity \\
\hline Valid or need-to-evaluate species & & \\
A. phoenicopteri (Lühe, 1898) Dietz, 1909 & Tunisia, China & Valid (type species) \\
A. haematopi Ku and Chiu, 1979 & China & Valid \\
A. jeetai Chakrabarti, 1972 & India & Need to study \\
A. kurogamo Yamaguti, 1939 & Japan, China & Valid \\
A. lobatum Soota et al. 1970 & India & Need to study \\
A. loborchis Wang, 1977 & China & Valid \\
A. macracanthum Rybakov and Lukomskaya, 1988 & Russia & Valid \\
A. marilae Yamaguti, 1934 & Japan, Australia, China, Korea & Valid \\
A. melanittae Yamaguti, 1939 & Japan & Valid \\
A. ochthodromi Tubangui, 1933 & The Philippines, China & Valid \\
A. pagollae Cable et al. 1960 & Puerto Rico & Valid \\
A. paracharadrii Velasquez, 1964 & The Philippines & Valid \\
A. spinulosum Johnston, 1917 & Australia, Japan, Taiwan, USA, Ukraine, Kuwait, & Valid \\
A. squatarolae Yamaguti, 1934 & New Zealand & \\
A. tyosenense Yamaguti, 1939,c & Japan, Australia, China & Valid \\
Species synonymized with A. spinulosum & Korea, Japan & Valid \\
A. cambellense Soota et al. 1970 & India & Syn. by Fischthal and Kuntz [14] \\
A. charadrii Yamaguti, 1939 & Japan, China, Europe & Syn. by Soota et al. [23] \\
A. longivitellatum Oschmarin, 1956 & Russia & Syn. by Skrjabin and Bashkirova [24] \\
A. spinulosum suzugamo Yamaguti, 1939 & Japan, China & Syn. by Skrjabin and Bashkirova [24] \\
\hline
\end{tabular}

aBased on the literature $[5-7,11,14,18,19,25,39-41]$

bHuman infections were reported in Korea [9].

${ }^{\circ}$ This species was considered a synonym of $A$. kurogamo by Skrjabin and Bashkirova [24] and Chen [25]. However, Chai et al. [9] re-examined the original specimens deposited in Meguro Parasitological Museum in Tokyo, Japan and concluded that the 2 species are valid because of various differential morphologies. 


\section{DISCUSSION}

A. phoenicopteri, the type species, was first reported in Europe (Tunisia) in 1898 (described under the name Echinostomum phoenicopteri) [28]. Subsequently, A. spinulosum was discovered from the golden plover Charadrius dominicus near Sydney, Australia [13]. Thereafter, a third species, A. ochthodromi, was described from the Philippines [34]. Yamaguti [4,5] described 7 new species in Japan (6 species) and Korea (1 species), which included A. charadrii Yamaguti, 1939, A. kurogamo, A. marilae, A. melanittae, A. spinulosum suzugamo Yamaguti, 1939, A. squatarolae, and A. tyosenense. Later, Acanthoparyphium longivitellatum Oschmarin, 1956 was reported in Russia. However, Skrjabin and Bashkirova [24] synonymized A. spinosulum suzugamo and A. longivitellatum as synonyms of A. spinulosum. Soota et al. [23] synonymized $A$. charadrii as a synonym of $A$. spinulosum. Skrjabin and Bashkirova [24] and Chen [25] synonymized $A$. tyosenense with A. kurogamo; however, this synonymy was denied by Chai et al. [9] because of their different body shape and position of the acetabulum and testes [5]. In Puerto Rico and the Philippines, A. pagollae and A. paracharadrii were described, respectively [29,31]. In India, Acanthoparyphium cambellense Soota et al., 1970 [23], A. lobatum Soota et al., 1970 [32], and A. jeetai Chakrabarti, 1972 [33] were described. However, Fischthal and Kuntz [14] synonymized A. cambellense with A. spinulosum. In China, A. haematopi and A. loborchis were described in 1970 and 1979, respectively [25]. The most lately reported species was A. macracanthum from Russia [30]. Thus, in the genus Acanthoparyphium, 19 species have been described, and among them 15 species are now recognized as valid or 'need-to-evaluate' species (Table 3). Geographically, A. spinulosum is the most widely distributed species.

The new species is morphologically very close to A. spinulosum. The drawing of A. spinulosum adult in the original report [13] showed that the 2 testes are both globular being not consistent with the feature of the new species. However, among the worm description within the text of the original report the posterior testis was described as a longitudinally elongate form [13]. In another report which described the adult worm of $A$. spinulosum, the 2 testes were drawn as globular (anterior one) and almost globular (posterior one) with no description of the testes morphology within the text [6]. However, a third drawing of an adult A. spinulosum from California, USA showed that the posterior testis is longitudinally elongated just like in our specimens, and in the text, it is written as 'The ante- rior testis is usually wider and shorter than the posterior.' [7]. Therefore, we considered that the morphology of the posterior testis is not a differential character between the new species and A. spinulosum. Rather, the larger egg size and the more limited distribution of vitelline follicles in the new species (see Remarks) could be considered as significant differential characters between adults of the new species and A. spinulosum. The size of the metacercariae was also different between the 2 species. In the new species, the diameter of the metacercariae was $0.203-0.226 \mathrm{~mm}$ but the diameter of A. spinulosum metacercariae was $0.18-0.20 \mathrm{~mm}$, smaller than the new species.

The new species is different biologically from A. spinulosum. In our study, the natural second intermediate host was 2 species of brackish water bivalves, $R$. philippinarum and C. chinensis. However, in Australia, the first intermediate host was 2 species of brackish water gastropods, Pyrazus australis and Salinator fragilis, and the latter gastropod species was experimentally used to obtain the metacercariae [6]. In USA $[7,35]$ and Kuwait [18], brackish water gastropod species, namely, Cerithidea californica (syn. Cerithidea hegewischi californica) and Cerithidea cingulata, respectively, were confirmed to be the first and second intermediate host. In USA, a bivalve species, Crassostrea virginica (a species of oysters), was also found to be a second intermediate host for A. spinulosum [15,36]. Information obtained so far indicates that the new species takes bivalve snails as the second (possibly also the first) intermediate host, whereas A. spinulosum takes gastropod and bivalve snails as the first and/or second intermediate host.

Nevertheless, morphological and biological differences alone seem to be not enough for a definite identification of Acanthoparyphium spp. Thus, we used molecular analysis of our specimens (adults and metacercariae) based on 5.8S rRNA, $28 \mathrm{~S}$ rRNA, and cox1 genes. Some difficulties were also met in molecular analysis largely because of the lack of enough information on Acanthoparyphium spp. in GenBank to compare with our specimens. Under the diagnosis of A. spinulosum, there are only 2 depositions, one from USA (KM880017) (5.8S rRNA) and the other from Ukraine (KT956939) (28S rRNA). Another isolate (assumed as Cercaria queenslandae I Canon, 1978) of A. spinulosum based on 28S rRNA from a cerithiid gastropod Clypeomorus batillariaeformis in southern Great Barrier Reef, Queensland, Australia has been deposited under the name Acanthoparyphium sp. (MH257769) [22]. This isolate was molecularly almost identical (99.6-100\% identical) with A. spinulosum from Ukraine (KT956939) and it is strongly sug- 
gested that these cercariae from Australia might be those of $A$. spinulosum. However, it is mentioned in the paper that the Cercaria queenslandae I Cannon, 1978 had 25 collar spines, which is inconsistent with the diagnosis of Acanthoparyphium [22]. Thus, it is possible that $C$. queenslandae I might have been a different species belonging to the Himasthlinae.

The homologies between our samples (metacercariae and adults) and A. spinulosum from USA (KM880017), our samples and A. spinulosum from Ukraine (KT956939), and our samples and Acanthoparyphium sp. from Queensland (MH257769; cercaria) were $96.1 \%, 97.9 \%$, and $98.1 \%$, not high enough for them to be identical. The sequences of these nuclear genes seem to be not so highly variable within the same species of the Echinostomatidae, for example, $97.8 \%$ between Echinostoma mekongi (MT409017 in 5.8S rRNA) [37] and Echinostoma paraensei (AF336233 in 5.8S rRNA), 2 different species of Echinostoma. It is also referable that, using a molecular study, Tkach et al. [19] obtained 2 Acanthoparyphium spp., including A. spinulosum from Ukraine (KT956939) and Acanthoparyphium n. sp. from USA (KT956940); their genetic identity based on $28 \mathrm{~S}$ rRNA was $98.0 \%$, but the 2 isolates were treated as different species.

In cox 1 gene, there is no nucleotide deposition of A. spinulosum in GenBank. Thus, we could not compare our samples directly with A. spinulosum. Instead, we could compare the sequences of our samples with those reported under the name Acanthoparyphium sp. Within the genus Acanthoparyphium, cox 1 sequences of 6 isolates or types, i.e., 1 isolate from Kuwait (MG792058; unpublished) and 5 types from New Zealand [38], including Acanthoparyphium sp. A (KJ956255), B (KJ 956279), C (FJ765464), D (KJ956288), and E (KJ956289), are available. Our samples revealed low homologies with these isolates or types, $83.5-86.9 \%$, and it seems that the new species is considered not homologous with these 2 groups. However, it was surprising to see that cox 1 sequences between different types (A-E) of Acanthoparyphium sp. from New Zealand also showed marked variation from $84.0 \%$ to $86.9 \%$. The 5 types (A-E) reported from New Zealand may constitute 2 or more species. In our samples, the cox 1 sequences between metacercariae and adults were only $94.7 \%$, considerably lower than expected. Further study is needed to confirm whether this low homology in cox 1 sequences was due to an intraspecific variation or reflects distinct genetic lineages.

\section{ACKNOWLEDGMENTS}

We appreciate the staff of Institute of Parasitic Diseases, Korea Association of Health Promotion, Seoul, Korea who helped surveys on parasites in marine clams on Aphae-do Island, Shinan-gun, Jeollanam-do, Republic of Korea during 2018-2020.

\section{CONFLICT OF INTEREST}

We declare that there is no conflict of interest related to this study.

\section{REFERENCES}

1. Chai JY. Echinostomes in humans. In Fried B, Toledo R, eds, The Biology of Echinostomes. New York, USA. Springer. 2009, pp 147-183.

2. Chai JY. Chapter 19. Echinostomes. In Xiao L, Ryan U, Feng Y, eds, Biology of Foodborne Parasites. Boca Raton, USA. CRC Press, Taylor \& Francis Group. 2015, pp 427-443.

3. Chai JY. Human Intestinal Fluke: From Discovery to Treatment and Control. Dordrecht, The Netherlands. Springer Nature. 2019, pp 1-549.

4. Yamaguti S. Studies on the helminth fauna of Japan. Part 3. Avian trematodes, II. Jpn J Zool 1934; 5: 543-583.

5. Yamaguti S. Studies on the helminth fauna of Japan. Part 25. Trematodes of birds, IV. Jpn J Zool 1939; 8: 129-210.

6. Bearup AJ. Life history of Acanthoparyphium spinulosum Johnston, 1917 (Trematoda: Echinostomatidae). Austral J Zool 1960; 8: 217-225. https://doi.org/10.1071/ZO9600217

7. Martin WE, Adams JE. Life cycle of Acanthoparyphium spinulosum Johnston, 1917 (Echinostomatidae: Trematoda). J Parasitol 1961; 47: 777-782. https://doi.org/10.2307/3275470

8. Velasquez CC. Life history of Acanthoparyphium paracharadrii sp. n. (Trematoda: Echinostomatidae). J Parasitol 1964; 50: 261-265. https://doi.org/10.2307/3276282

9. Chai JY, Han ET, Park YK, Guk SM, Lee SH. Acanthoparyphium tyosenense: the discovery of human infection and identification of its source. J Parasitol 2001; 87: 794-800. https://doi.org/10.1645/00223395(2001)087[0794:attdoh]2.0.CO;2

10. Martorelli SR, Poulin R, Mouritsen KN. A new cercaria and metacercaria of Acanthoparyphium (Echinostomatidae) found in an intertidal snail Zeacumantus subcarinatus (Batillaridae) from New Zealand. Parasitol Int 2006; 55: 163-167. https://doi.org/10.1016/ j.parint.2006.02.001

11. Han ET, Chai JY. Mactra veneriformis, an intertidal clam, as a new second intermediate host for Acanthoparyphium marilae (Digenea: Echinostomatidae). Korean J Parasitol 2008; 2: 101-104. https:// doi.org/10.3347/kjp.2008.46.2.101

12. Leung TLF, Keeney DB, Poulin R. Cryptic species complexes in 
manipulative echinostomatid trematodes: when two become six. Parasitology 2009; 136: 241-252. https://doi.org/10.1017/ S0031182008005374

13. Johnston SJ. On the trematodes of Australian birds. J Royal Soc New South Wales 1917; 50: 187-261.

14. Fischthal JH, Kuntz RE. Some digenetic trematodes of mammals from Taiwan. Proc Helminthol Soc Wash 1976; 42: 149-157.

15. Little JW, Hopkins SH, Schlicht FG. Acanthoparyphium spinulosum (Trematoda: Echinostomatidae) in oysters of Port Isabel, Texas. J Parasitol 1966; 52: 663.

16. Bass HS, LeFlore WB. In vitro excystment of the metacercaria of Acanthoparyphium spinulosum (Trematoda: Echinostomatidae). Proc Helminthol Soc Wash 1984; 51: 149-153.

17. Nguyen AT, Kuwata C, Kuris AM. A synthetic workflow for a coordinated direct observation and genetic tagging applied to a complex host-parasite interaction. Parasitol Res 2015; 114: 20152021. https://doi.org/10.1007/s00436-015-4437-8

18. Abdul-Salam J, Al-Taqi M, Sreelatha BS. Ultrastructure of metacercarial cyst wall of Acanthoparyphium spinulosum (Digenea: Echinostomatidae). J Parasit Dis 2007; 31: 108-113.

19. Tkach VV, Kudlai O, Kostadinova A. Molecular phylogeny and systematics of the Echinostomatoidea Looss, 1899 (Platyhelminthes: Digenea). Int J Parasitol 2016; 46: 171-185. https://doi. org/10.1016/j.ijpara.2015.11.001

20. Yamaguti S. Systema Helminthum. Vol. I. Part I. The Digenetic Trematodes of Vertebrates. New York, USA. Interscience Publishers Inc. 1958, pp 1-979.

21. Yamaguti S. Synopsis of Digenetic Trematodes of Vertebrates. Tokyo, Japan. Keigaku Publishing Co. 1971, pp 1-1073.

22. Huston DC, Cutmore SC, Cribb TH. Molecular systematics of the digenean community parasitizing the cerithiid gastropod Clypeomorus batillariaeformis Habe \& Kusage on the Great Barrier Reef. Parasitol Int 2018; 67: 722-735. https://doi.org/10.1016/j.parint. 2018.07.008

23. Soota TD, Srivastava CB, Ghosh RK. Studies on the helminth fauna of the Great Nicobar Island. Part I. Trematoda. Proc Indian Acad Sci (Section B) 1970; 72: 241-250.

24. Skrjabin KI, Bashkirova EI. Family Echinostomatidae Dietz, 1909. In Skrjabin KI, ed, Trematodes of Animals and Man. Moscow-Leningrad, Russia. Izdatelstvo Akademii Nauk SSSR. 1956, pp 51-930 (in Russian).

25. Chen HT. Fauna Sinica. Platyhelminthes. Trematoda. Digenea (I). Beijing, China. Science Press, 1985, pp 1-697 (in Chinese).

26. Boyce K, Hide G, Craig PS, Harris PD, Reynolds C, Pickles A, Rogan MT. Identification of a new species of digenean Notocotylus malhamensis n. sp. (Digenea: Notocotylidae) from the bank vole (Myodes glareolus) and the field vole (Microtus agrestis). Parasitology 2012; 139: 1630-1639. https://doi.org/10.1017/S0031182012000911

27. Leung TLF, Donald KM, Keeney DB, Koehler AV, Peoples RC, Poulin R. Trematode parasites of Otago Harbour (New Zealand) soft-sediment intertidal ecosystems: life cycles, ecological roles and DNA barcodes. NZ J Marine Freshwat Res 2009; 43: 857865. https://doi.org/10.1080/00288330909510044

28. Dietz E. Die Echinostomiden der Vögel. Zool Jarb 1910; 12 (suppl): 265-512 (in German).

29. Cable RM, Conner RS, Balling JW. Digenetic trematodes of Puerto Rican shore birds. Sci Surv Puerto Rico Virgin Island (by New York Acad Sci) 1960; 17: 187-255.

30. Rybakov AV, Lukomskaya OG. On the life cycle of Acanthoparyphium macracanthum sp. n. (Trematoda: Echinostomatidae). Parazitologiya 1988; 22: 224-229 (in Russian).

31. Velasquez CC. Life history of Acanthoparyphium paracharadrii sp. n. (Trematoda: Echinostomatidae). J Parasitol 1964; 50: 261-265. https://doi.org/10.2307/3276282

32. Soota TD, Srivastava CB, Ghosh RK. The helminth fauna of Andaman and Nicobar Islands, Trematoda. Rec Zool Surv India 1972; 67: 281-285.

33. Chakrabarti S. On a trematode parasite Acanthoparyphium jeetai n. sp. (Echinostomatidae: Himasthlinae) from little stint, Calidrus (Calidrus) minuta (Leiser) from Chennal Coast, India. Rec Zool Surv India 1972; 103: 71-78.

34. Tubangui MA. Trematode parasites of Philippine vertebrates, VI. Description of new species and classification. Phil J Sci 1933; 52: 167-197.

35. Torchin ME, Byers JE, Huspeni TC. Differential parasitism of naive and introduced snails: replacement of a parasite fauna. Biol Invas 2005; 7: 885-894. 35. https://doi.org/10.1007/s10530-0042967-6

36. Little JW. The excystment, growth and reproduction of Acanthoparyphium spinulosum Johnston, 1917 (Trematoda) in chicks fed various diets. Parasitology 1970; 60: 61-78. https://doi.org/10.1017/ S0031182000077258

37. Cho J, Jung BK, Chang T, Sohn WM, Sinuon M, Chai JY. Echinostoma mekongi n. sp. (Digenea: Echinostomatidae) from riparian people along the Mekong River in Cambodia. Korean J Parasitol 2020; 58: 431-443. https://doi.org/10.3347/kjp.2020.58.4.431

38. Keeney DB, Palladino J, Poulin R. Broad geographic analyses reveal varying patterns of genetic diversity and host specificity among echinostome trematodes in New Zealand snails. Parasitology 2015; 142: 406-415. https://doi.org/10.1017/S0031182014001279

39. Ito J. Studies on the brackish water cercariae in Japan. III. Three new echinostome cercariae in Tokyo Bay, with a list of Japanese echinostome cercariae. Jpn J Med Sci Biol 1957; 10: 439-453.

40. Nguyen AT. Genetic diversity and its relationship to host-specificity of a trematode parasite (Acanthoparyphium spinulosum). Ph.D. Thesis to University of California (Santa Barbara), USA. 2012, pp $1-87$.

41. Richard J. Acanthoparyphium charadrii Yamaguti, 1939 chez Squatarola squatarola. Mem Mus Nat Hist Natur s A Zool 1966; 41: 125126 (in French). 
